JOANNA FiLIPOWICZ

Uniwersytet Łódzki

Wydział Nauk o Wychowaniu

Instytut Psychologii

91-433 Łódź, ul. Smugowa 10/12

e-mail: joanna90@vp.pl

\title{
SYMPATYCZNOŚĆ TWARZY - WSTĘP DO OCENY UWARUNKOWAŃ
}

\begin{abstract}
Abstrakt. Celem niniejszego badania była wstępna eksploracja uwarunkowań sympatyczności twarzy. Jako że sympatyczność nie była wcześniej przedmiotem zainteresowania polskich badaczy, poszukiwano potwierdzenia, że jest ona zmienną odrębną od atrakcyjności fizycznej, a także możliwą do instynktownej oceny wyłącznie na podstawie krótkotrwałej ekspozycji twarzy. Sprawdzano też, czy ekspresja emocjonalna ma wpływ na to, jak oceniana jest sympatyczność oraz próbowano rozstrzygnąć, czy jest to cecha obiektywna, czy też istnieją różnice między ludźmi w jej postrzeganiu.

Badaniem objęto 82 osoby (41 mężczyzn i 41 kobiet) w wieku od 18 do 30 lat. Wyniki świadczą o tym, że sympatyczność twarzy należy rozpatrywać jako zmienną odrębną od atrakcyjności fizycznej i podlegającą subiektywnej ocenie. Wykazano, że pozytywna ekspresja emocjonalna może sprzyjać wysokim ocenom sympatyczności. Wiele poruszonych kwestii dotyczących sympatyczności twarzy wciąż wymaga rozstrzygnięcia ze względu na ograniczenia niniejszych badań, jednak można mieć nadzieję, że dadzą one asumpt do przyszłych rozważań.
\end{abstract}

Słowa kluczowe: sympatyczność, twarz, pierwsze wrażenie.

\section{POJĘCIE SYMPATYCZNOŚCI}

Człowiek jest istotą społeczną i jedną z jego najważniejszych potrzeb jest przynależność do grupy (Baumeister, Leary, 1995). Tak naprawdę życie pośród ludzi do pewnego stopnia zaspokaja też potrzebę bezpieczeństwa - łatwiej jest zwalczać zagrożenia jako zbiorowość niż w pojedynkę. Żeby jednak zostać włączonym w daną grupę, trzeba najpierw zdobyć przychylność jej członków. Co przesądza o tym, czy jednostka zdobędzie zaufanie innych i nie zostanie odrzucona? Covin (2011) uważa, że jest to sympatyczność (ang. likeability) i wiąże ją z ewolucyjnie ukształtowaną potrzebą bycia lubianym. Według niego wywodzi się ona $\mathrm{z}$ chęci bycia zaakceptowanym przez grupę, do której przynależność zapewnia większe szanse 
na przetrwanie. Kiedy ono jest stawką, już pierwsze wrażenie może zdecydować o tym, jak dana osoba zostanie oceniona. Badania pokazują, że już przy ekspozycji trwającej $39 \mathrm{~ms}$ i bez udziału świadomej analizy, człowiek jest w stanie określić, czy dana twarz jest zagrażająca, w sposób zgodny z ocenami dokonywanymi przy dłuższym czasie ekspozycji, w sposób świadomy (Bar, Neta, Linz, 2006). Ale spójne sądy dotyczące innych cech też mogą być dokonywane stosunkowo szybko. W eksperymencie Willisa i Todorova (2006) badani oceniali, czy twarze eksponowane przez $100 \mathrm{~ms}$ są atrakcyjne, sympatyczne, godne zaufania, kompetentne oraz agresywne. Decyzje te nie różniły się istotnie od tych podejmowanych przy dłuższej ekspozycji, co dowodzi, że wnioskowanie o cechach charakteru na podstawie wyglądu twarzy jest czysto intuicyjne i nie wymaga dokładnego przyglądania się. Zatem zdobycie akceptacji grupy, społeczne „być albo nie być”, może być uzależnione od wyrazu twarzy człowieka - sympatycznego bądź nie. Kwestią otwartą pozostaje, co właściwie jest przez ludzi uznawane za sympatyczne.

Słowo likeable (lub likable) wydaje się najlepiej dopasowanym znaczeniowo angielskim odpowiednikiem polskiego „sympatyczny”. Można by je rozumieć dosłownie jako „mający potencjał bycia lubianym” (lub „zasługujący na bycie lubianym", jak podaje słownik pod redakcją A. S. Hornby’ego, 1974). Polskie słowo „sympatyczny” oznacza natomiast tyle, co „budzący sympatię i sprawiający przyjemne wrażenie" ${ }^{1}$ zatem akcentuje nieco bardziej powierzchowne aspekty opisywanej postaci. Mimo to, można uznać, że „sympatia” i „lubienie” są na tyle bliskoznaczne, aby móc traktować angielskie likeable jako odpowiednik przymiotnika „sympatyczny”. Wyjaśnienie tej lingwistycznej zależności jest o tyle ważne, że nie istnieje jednolita teoria wyjaśniająca, czym jest lub jak działa sympatyczność, a wszelkie badania empiryczne uwzględniające tę zmienną zostały opisane w języku angielskim. Aby lepiej zrozumieć znaczenie sympatyczności, można zatem odwołać się do istniejących badań na temat związanych z nią zmiennych oraz efektów, jakie wywiera na ludzkie zachowanie.

\section{ZMIENNE ZWIĄZANE Z SYMPATYCZNOŚCIĄ}

Skoro sympatyczność jest potencjałem bycia lubianym, aby dociec, co czyni człowieka sympatycznym, należałoby odpowiedzieć na pytanie, co ludzie lubią w innych. Kilkoro badaczy podjęło się tego zadania. Cottrel, Neuberg i Li (2007) poprosili grupę studentów o skonstruowanie idealnego człowieka z wcześniej przygotowanego zestawu cech, określając jak ważna jest obecność każdej z nich i wskazując jedną najważniejszą. Przymiotem najwyżej cenionym przez badanych (i jedynym istotnie ważniejszym od innych) okazało się bycie godnym zaufania (ang. trustworthiness). W dalszych próbach wykazano, że to, które cechy

${ }^{1}$ http://sjp.pwn.pl/slownik/2525677/sympatyczny [dostęp: 25.07.2013]. 
ludzie uważają za istotne, zależy od rodzaju znajomości, jaką utrzymują z opisywaną osobą (np. pracownik, członek rodziny, przyjaciel, znajomy czy członek drużyny sportowej). Mimo że inne przymiotniki okazywały się najważniejsze dla poszczególnych typów relacji (np. inteligencja u członka grupy naukowej), nadal dla większości najczęściej wybierane było bycie godnym zaufania. W przypadku przyjaciela przymiotami, które pojawiły się z częstością wyższą od przypadkowej, były również podobieństwo i ekstrawersja (Cottrel, Neuberg, Li, 2007). Podobnie Sprecher i Regan (2002) poprosiły badanych o ocenę każdej cechy z przygotowanej wcześniej listy pod względem tego, jak bardzo ją lubią u osoby w danym typie bliskiej relacji (np. małżonek, partner seksualny, przyjaciel) i jak bardzo jest ważne, by ta osoba się nią odznaczała. Wyłoniono trzy atrybuty, które okazały się najważniejsze dla wszystkich rodzajów związków. Były to: „ciepło i życzliwość”, „ekspresywność i otwartość” oraz „poczucie humoru”. Nawet cechy zazwyczaj uznawane za istotne pod względem reprodukcyjnym, jak atrakcyjność fizyczna czy status społeczny, okazały się mniej pożądane. Oczywiście nasuwa się wniosek, że to, jakie zalety są uznawane za bardziej istotne, zależy od listy, z której są wybierane. Mniejsze znaczenie ma rodzaj relacji, skoro - przynajmniej dla tych bliższych - zazwyczaj to samo okazuje się lubiane. Można więc przypuszczać, że bycie godnym zaufania, ciepłym, życzliwym, otwartym i zabawnym daje większe szanse na zdobycie sympatii innych ludzi niż atrakcyjność fizyczna czy bogactwo.

W lepszym zrozumieniu tego, jakie osoby są uznawane za sympatyczne, może pomóc zapoznanie się ze Skalą Sympatyczności (The Reysen Likability Scale) skonstruowaną przez Reysena (2005). Jest ona tak zbudowana, że można za jej pomocą ocenić zarówno osobę, z którą przed chwilą się rozmawiało, jak i osobę na filmie lub zdjęciu. Autor twierdzi, że tym, co podnosi postrzeganą sympatyczność, jest atrakcyjność fizyczna, podobieństwo (do osoby oceniającej) i prawione komplementy (Reysen, 2005). Jednakże stworzone przez niego narzędzie zawiera również pozycje odnoszące się m.in. do ciepła, przystępności czy też tego, czy daną osobę warto prosić o radę albo się z nią przyjaźnić. Skala została uznana za rzetelną i trafną (Reysen, 2005), zatem można przypuszczać, że wymienione zmienne faktycznie mają duży wpływ na ogólną postrzeganą sympatyczność człowieka.

Pomiar sympatyczności umożliwia jeszcze jedno narzędzie - Skala Wiarygodności Świadka (Witness Credibility Scale) (Brodsky, Griffin, Cramer, 2010), skonstruowana dla potrzeb wymiaru sprawiedliwości. Wynika z niej, że świadek wiarygodny to taki, który jest pewny siebie (ang. confident), sympatyczny, godny zaufania i zorientowany (ang. knowledgeable). Cechy te mierzone są przez odrębne podskale, które okazały się skorelowane w sposób istotny statystycznie. Można stąd wnioskować, że w dużej części przypadków osoby uznawane za sympatyczne odznaczają się również pozostałymi wymienionymi cechami.

$\mathrm{Na}$ podstawie przywołanej literatury można sądzić, że sympatyczność jest konstruktem bardzo podobnym bądź nawet identycznym z pojęciem atrakcyjności interpersonalnej. Wedle teorii decydują o niej następujące cechy: bliskość, 
czyli częstość kontaktów, atrakcyjność fizyczna, podobieństwo (ale czasem też komplementarność) oraz otrzymywane pochwały, a także to, ile wysiłku wymagało zjednanie sobie jej przychylności (Aronson, Wilson, Akert, 1997). Trudno się oprzeć wrażeniu, że rzeczywiście są to elementy mogące konstruować pozytywną postawę wobec kogoś, sprawiać, iż jest on lubiany. Co zatem odróżnia sympatyczność od atrakcyjności interpersonalnej? Otóż, jak zostało wspomniane, sympatyczność postrzega się raczej jako potencjał bycia lubianym, możliwość, która nie musi zostać zrealizowana. Wobec braku dokładnej definicji pozostaje opierać się na instynktownym, potocznym rozumieniu tego słowa. Według niego, podczas gdy atrakcyjność interpersonalna wyjaśnia, dlaczego jedną osobę lubi się bardziej niż inną, sympatyczność może być tym, co sprawia, że pytanie o godzinę kieruje się do tego, a nie innego nieznajomego. Podczas gdy pierwsza $\mathrm{z}$ cech zawiera aspekt relacyjny, wiąże się z postawą bardziej emocjonalną, druga wydaje się powierzchowna, odnosi się do pozytywnego postrzegania wyglądu lub zachowań człowieka znanego co najwyżej z nazwiska. Nawet Aronson, Wilson i Akert (1997) w rozdziale poświęconym atrakcyjności interpersonalnej używają wielokrotnie określenia „sympatyczny”. Kontekst wskazuje, że gdy piszą o „sympatycznym zachowaniu”, mają na myśli takie, które jest zgodne z zasadami współżycia społecznego, czyli miłe, uprzejme, kulturalne. Potencjalnie może ono sprawić, że ludzie będą mieli ochotę nawiązać znajomość z osobą je przejawiającą, ale nie jest czynnikiem wystarczającym i na pewno nie może być utożsamiane $\mathrm{z}$ atrakcyjnością interpersonalną. Jednakże prawdopodobnie mając do wyboru przebywanie czy interakcję z osobą wyglądającą bądź zachowującą się sympatycznie lub nie, większość ludzi wybrałaby tę pierwszą. Podsumowując, należy stwierdzić, że sympatyczność nie jest tożsama z atrakcyjnością interpersonalną, choć, szczególnie w odniesieniu do początkowego etapu znajomości, mogą manifestować się w bardzo podobny sposób. Atrakcyjność jest jednak konstruktem bardziej złożonym i odnosi się do osób pozostających w relacji emocjonalnej, podczas gdy sympatyczność dotyczy raczej powierzchownych interakcji, naznaczonych jedynie prawdopodobieństwem nawiązania bliższego kontaktu.

Sympatyczność można byłoby również pomylić z atrakcyjnością fizyczną, wiadomo bowiem, że ludzie mają tendencję do przypisywania pozytywnych cech osobom, które uważają za piękne. Należałoby tu znów odwołać się do badań, które pokazują, że przynajmniej na poziomie deklaracji atrakcyjność fizyczna jest cechą drugorzędną pod względem znaczenia w relacjach interpersonalnych (Sprecher, Regan, 2002). Również intuicja podpowiada, że osoby uważane za piękne nie zawsze wydają się godne zaufania, a wręcz przypisuje im się takie cechy, jak wyniosłość czy niedostępność. Warto byłoby jednak rozstrzygnąć empirycznie, czy rzeczywiście sympatyczność można postrzegać jako nową, osobną zmienną, czy też jest to tylko manifestacja innych cech, np. atrakcyjności fizycznej. Zbadanie istoty tego pojęcia i zróżnicowanie go z innymi mogłoby otworzyć pole do dalszej eksploracji znaczenia sympatyczności w relacjach interpersonalnych. 


\section{ZMIENNE ZWIĄZANE Z SYMPATYCZNOŚCIĄ TWARZY}

Jak zostało wspomniane wcześniej, ludzie potrafią w krótkim czasie wysnuć daleko idące wnioski na temat czyichś cech charakteru, bazując wyłącznie na wyglądzie jego twarzy. Istnieje szereg badań sprawdzających, co sprawia, że człowiek wydaje się sympatyczny lub nie na pierwszy rzut oka, np. w sytuacji, gdy dostępne jest tylko jego zdjęcie. W badaniach tych zwraca się uwagę na takie cechy, jak wiek, nadwaga oraz wyrażane emocje.

W eksperymentach Reysena (2006) uczestnicy oceniali na stworzonej przez niego skali sympatyczność osób widocznych na filmie lub zdjęciu, które uśmiechały się, śmiały (szczerze bądź udawały rozbawienie) lub miały neutralny wyraz twarzy. Te ostatnie wydawały się badanym w istotny sposób mniej sympatyczne niż osoby wyrażające radość (niezależnie od jej autentyczności), zarówno gdy osądzali na podstawie filmu, jak i zdjęcia. Szanse na zyskanie sympatii mogą być zatem większe, jeśli człowiek często się uśmiecha. Na to, jak jest się postrzeganym, mają jednak również wpływ kwestie, których nie da się łatwo zmodyfikować. $\mathrm{Na}$ przykład twarze starszych ludzi są oceniane jako mniej atrakcyjne, sympatyczne, charakterystyczne, nastawione na rozwój (ang. growth-oriented) i energetyczne niż twarze młodsze, chociaż starsi badani generalnie oceniają twarze bardziej pozytywnie (Ebner, 2008). Również nadwaga ma negatywny wpływ na postrzeganą atrakcyjność i sympatyczność twarzy (Galper, Weiss, 1975). Bruce i McDonald (1993) sugerują, że rozpoznawalność twarzy zależy od jej sympatyczności. W ich badaniach rzeczywiście uczestnicy lepiej rozpoznawali twarze, które uznali wcześniej za sympatyczne niż te, które uznali za niesympatyczne. Jednak może to świadczyć o tym, że sympatię wzbudzają rysy bardziej charakterystyczne pod jakimś względem, co sprzyja zapamiętywaniu.

Warte uwagi są również badania Larrance i Zuckermana (1981). Inspirują się oni stereotypem mówiącym, że to, co piękne jest też dobre, sprawdzając, czy osoby o atrakcyjnych fizycznie twarzach i sympatycznych głosach mają większe zdolności interpersonalne. Uzyskane przez nich wyniki świadczą, że istotnie tacy ludzie potrafią z większą trafnością wysyłać emocjonalne komunikaty pozawerbalne. Nie wiadomo, czy dotyczy to również osób o sympatycznych twarzach - mimo że doświadczenie wskazuje, iż atrakcyjność fizyczna to nie to samo, co sympatyczność, to jednak w wielu badaniach ich pomiary zdają się dawać podobne efekty (np. Ebner, 2008; Galper, Weiss, 1975).

Ze względu na to, że sympatyczność jako czynnik, który może wpływać na interakcje międzyludzkie, w ogóle nie była do tej pory w rodzimej literaturze naukowej brana pod uwagę, zdecydowano się uwzględnić ją w badaniu eksperymentalnym, mając nadzieję, że da to asumpt do dalszych dociekań. Jak wspomniano, sympatyczność może być opisana jako „potencjał bycia lubianym” lub „budzenie sympatii”, jest jednak cechą na tyle powierzchowną, że może być z łatwością odczytana z twarzy człowieka, a nie musi wiązać się z istniejącą relacją. 
Postanowiono w takim razie skoncentrować się na sympatyczności twarzy, która może być obserwowana bez bezpośredniego kontaktu, np. na fotografiach. $\mathrm{Na}$ podstawie literatury przypuszczano, że instynktowne, potoczne rozumienie pojęcia sympatyczności pozwoli ochotnikom na jednoznaczną ocenę, czy dana twarz odznacza się tą cechą czy nie, bez dłuższego namysłu. Chciano jednak sprawdzić, czy istnieją różnice między ludźmi w zakresie tego, które twarze uznają za sympatyczne, czy może jest to cecha postrzegana obiektywnie i uda się uzyskać zgodne oceny. Postanowiono również ustalić, czy istnieje związek między sympatycznością twarzy a atrakcyjnością fizyczną oraz czerpaniem przyjemności z patrzenia na daną osobę. Ze względu na dotychczasowy brak polskich badań na tym polu uznano, że poszerzenie wiedzy na temat sympatyczności może być przydatne z punktu widzenia psychologii społecznej.

\section{METODA}

W badaniu wzięły udział 82 osoby rekrutowane metodą śnieżnej kuli. Dobór był celowy ze względu na płeć: przebadano 41 kobiet (50\%) i 41 mężczyzn (50\%). Ochotnicy zostali losowo podzieleni na cztery grupy eksperymentalne różniące się wersją wyświetlanej prezentacji. Badani mieli od 18 do 30 lat $(M=24,18$; $S D=2,64)$. Przeprowadzona jednoczynnikowa analiza wariancji nie wykazała istotnych różnic średnich wieku między poszczególnymi grupami eksperymentalnymi: $F(3,78)=1,30 ; p=0,28$.

54 osoby $(65,9 \%)$ były w chwili badania studentami uczelni wyższych. Najliczniej wśród nich reprezentowani byli studenci prawa $(11,1 \%)$, historii i pedagogiki (po 7,4\%) oraz chemii i zarządzania (po 5,6\%). Spośród osób niebędących w chwili badania studentami (34,1\% ogółu badanych) najliczniejsze grupy stanowili informatycy i sprzedawcy (po 10,7\%).

Na potrzeby opracowania stworzono materiał bodźcowy w postaci czterech zestawów zdjęć, za pomocą których manipulowano znakiem nastroju przekazywanego przez nadawcę oraz jego sympatycznością.

$\mathrm{Na}$ stronach www.flickr.com oraz www.deviantart.com, za pomocą słów kluczowych, np. smile, happy, sad, emotion, portrait, szukano zdjęć twarzy wyrażających emocje. Drogą mailową poproszono grupę znajomych o nadsyłanie posiadanych zdjęć tego typu. Dokonując wstępnej selekcji, odrzucono fotografie, na których przedstawione osoby nie patrzyły prosto w obiektyw oraz zdjęcia czarno-białe, z elementami mogącymi odciągać uwagę od twarzy, z elementami częściowo zasłaniającymi twarz, a także takie, co do których trudno było jednoznacznie określić znak emocji. W pozostałym zbiorze starano się zrównoważyć liczbę zdjęć przedstawiających osoby starsze i młode, kobiety i mężczyzn, ekspresje emocji pozytywnych i negatywnych. W efekcie uzyskano zbiór 45 zdjęć, którym nadano numery porządkowe. $\mathrm{Z}$ tych, które posiadały jednolitego koloru ramki czy 
paski na krawędziach (czarne, białe), wycięto je. Nie wycinano umieszczonych na obrzeżach sygnatur autorów.

Tak przygotowany zestaw zdjęć poddano ocenie sędziów kompetentnych. $\mathrm{W}$ tym celu stworzono prezentację multimedialną, umieszczając $\mathrm{w}$ niej zdjęcia w losowej kolejności (korzystając $\mathrm{z}$ funkcji RANDBETWEEN w programie Microsoft Excel).

Prezentację skonstruowano według schematu: najpierw pojawiał się slajd z numerem zdjęcia wyświetlany przez 3 sekundy, następnie slajd ze zdjęciem, którego pojawieniu się towarzyszył dźwięk migawki wyświetlany przez 6 sekund, a na koniec slajd z prośbą o dokonanie oceny na arkuszu odpowiedzi wyświetlany przez 22 sekundy. Seria ta wyświetlana była 45 razy (osobno dla każdego zdjęcia z zestawu).

By zdjęcia zajmowały jak największą powierzchnię slajdów, ustalono wysokość $21 \mathrm{~cm}$ dla fotografii o orientacji pionowej i szerokość $28 \mathrm{~cm}$ dla orientacji poziomej (przy zachowaniu proporcji). Wszystkie zdjęcia wyrównano do środka w pionie i poziomie. Ustalono jednolicie czarne tło dla wszystkich slajdów.

Sędziowie kompetentni, którym prezentowano slajdy, dokonywali oceny na specjalnie skonstruowanych kwestionariuszach. Uwzględniono w nich następujące kryteria: „znak emocji” oraz „sympatyczność nadawcy”, a także zmienne kontrolowane: „intensywność ekspresji”, ,,autentyczność ekspresji”, ,atrakcyjność fizyczna nadawcy”, ,jakość zdjęcia”. Każdy z tych aspektów oceniany był osobno w odniesieniu do każdego zdjęcia z zestawu na 10-stopniowej skali poprzez zakreślenie odpowiedniej liczby. Skale do oceny poszczególnych zdjęć znajdowały się na osobnych stronach. Arkusze zostały spięte razem.

Rolę sędziów kompetentnych pełnili studenci IV roku psychologii: sześć kobiet i dwóch mężczyzn w wieku od 22 do 24 lat. Zajęli oni miejsca po dwóch stronach stołu, u szczytu którego stał laptop z włączoną prezentacją. Upewniono się, że wszyscy dobrze widzą ekran. Do oceny przystąpiono po przeczytaniu przez wszystkich instrukcji zawartej na początku arkusza odpowiedzi.

Dane uzyskane za pomocą sędziowania poddano analizie statystycznej, w wyniku której uzyskano średnie i odchylenia standardowe ocen poszczególnych aspektów dla każdego zdjęcia. Współczynnik zgodności ocen sędziów $W$ Kendalla wyniósł 0,$69 ; \chi^{2}(251 ; n=8)=1382,54 ; p<0,001$.

Na podstawie wartości średnich ocen pod względem kryterium „znak emocji” podzielono zdjęcia na pozytywne i negatywne, przyjmując 5,00 jako najwyższą dopuszczalną wartość dla fotografii negatywnych i 7,00 jako najniższą dopuszczalną wartość dla pozytywnych. Pozostałe zdjęcia odrzucono, pozostawiając w zbiorze 21 zdjęć prezentujących pozytywną ekspresję emocjonalną i 20 zdjęć prezentujących negatywną ekspresję emocjonalną. Każdy z powstałych zbiorów podzielono na dwa podzbiory po względem wartości średnich ocen sympatyczności nadawcy. Wśród zdjęć przedstawiających negatywne emocje jako najwyższą wartość tej średniej w grupie o niskiej sympatyczności przyjęto 4,75, zaś 
najniższą wartością w grupie o wysokiej sympatyczności było 4,88. W przypadku zdjęć prezentujących pozytywne ekspresje najwyższa wartość dla zbioru o niskiej sympatyczności wyniosła 8,25 , a najniższa wartość dla zbioru o wysokiej sympatyczności $-8,38$. Powstały w ten sposób cztery zbiory zdjęć:

1) 10 zdjęć przedstawiających nadawców o niskiej sympatyczności prezentujących negatywną ekspresję emocjonalną (zdjęcia „negatywne niesympatyczne”),

2) 10 zdjęć przedstawiających nadawców o wysokiej sympatyczności prezentujących negatywną ekspresję emocjonalną (zdjęcia „negatywne sympatyczne”),

3) 11 zdjęć przedstawiających nadawców o niskiej sympatyczności prezentujących pozytywną ekspresję emocjonalną (zdjęcia „pozytywne niesympatyczne”),

4) 10 zdjęć przedstawiających nadawców o wysokiej sympatyczności prezentujących pozytywną ekspresję emocjonalną (zdjęcia „pozytywne sympatyczne”).

W celu wyrównania liczebności grup odrzucono jedno zdjęcie ze zbioru 3. Kryterium była najniższa średnia dla zmiennej „sympatyczność” i najwyższe odchylenie standardowe (wskazujące na najniższą zgodność sędziów).

Za pomocą jednoczynnikowej analizy wariancji porównano średnie oceny pod względem wyodrębnionych kryteriów w wyłonionych zbiorach zdjęć (por. tab. 1). Zgodnie z oczekiwaniami nie wykazano istotnych różnic średnich między grupami w zakresie autentyczności ekspresji nadawcy, atrakcyjności nadawcy i jakości zdjęcia, natomiast odnotowano istotne różnice między zbiorami pod względem znaku emocji i sympatyczności nadawcy. Przy pomocy testu Levene'a wariancje wszystkich badanych zmiennych uznano za jednorodne (por. tab. 2), co pozwoliło na przeprowadzenie w dalszej kolejności testu porównań wielokrotnych Bonferroniego. Umożliwił on potwierdzenie, że znak ekspresji nadawcy na zdjęciach negatywnych był oceniany istotnie niżej niż na zdjęciach pozytywnych, natomiast sympatyczność twarzy nadawcy na zdjęciach niesympatycznych - istotnie niżej niż na zdjęciach sympatycznych. Wbrew przewidywaniom zaobserwowano też istotne różnice pomiędzy zbiorami zdjęć w zakresie intensywności ekspresji nadawcy. Wyniki uzyskane w teście porównań wielokrotnych Bonferroniego wskazały, że zdjęcia negatywne były oceniane na skali intensywności ekspresji istotnie niżej niż zdjęcia pozytywne. Można przypuszczać, że stało się tak, ponieważ ekspresja smutku intuicyjnie wydaje się bardziej zbliżona do neutralnego wyrazu twarzy niż uśmiech, będący wyrazem radości, podczas którego kurczą się mięśnie wokół oczu, a kąciki ust unoszą się ku górze. Zestawy zdjęć sympatycznych i niesympatycznych nie różniły się od siebie istotnie pod względem tego kryterium. Tak jak można było się spodziewać na podstawie literatury, oceny sympatyczności generalnie były wyższe przy pozytywnych ekspresjach osób na zdjęciach. Dla zebrania danych nie uwzględnionych w niniejszym artykule istotne było jednak stworzenie zestawów zdjęć różniących się sympatycznością w obrębie danego znaku emocji, natomiast różnice w ocenach sympatyczności pomiędzy warunkami pozytywnymi i negatywnymi o takiej samej zaklasyfikowanej sympatyczności (np. „pozytywne sympatyczne” i „negatywne sympatyczne”) 
nie miały większego znaczenia dla planowanego badania. Warto wspomnieć, że mimo wstępnej selekcji, mającej na celu zrównanie ilości fotografii twarzy osób różnej płci i w różnym wieku, po ocenie sędziów poszczególne zbiory różniły się pod względem tych zmiennych. Nie kontrolowano również, ile zdjęć osób o poszczególnych kolorach skóry trafia do poszczególnych zbiorów. Należy mieć na uwadze, że czynniki te mogą wpływać na postrzeganie twarzy, jednak uznano, iż dla celów niniejszego badania zmienne uwzględnione w arkuszu dla sędziów mają większe znaczenie.

Tabela 1. Porównanie czterech wyłonionych zbiorów zdjęć pod względem znaku emocji, sympatyczności nadawcy, intensywności ekspresji, autentyczności ekspresji, atrakcyjności nadawcy i jakości zdjęcia

\begin{tabular}{|l|c|c|c|c|c|c|c|c|c|c|c|}
\hline \multirow{2}{*}{$\begin{array}{c}\text { Kryterium } \\
\text { oceny }\end{array}$} & \multicolumn{2}{|c|}{$\begin{array}{c}\text { Zdjęcia } \\
\text { negatywne } \\
\text { niesympatyczne }\end{array}$} & \multicolumn{2}{c|}{$\begin{array}{c}\text { Zdjęcia } \\
\text { negatywne } \\
\text { sympatyczne }\end{array}$} & \multicolumn{2}{c|}{$\begin{array}{c}\text { Zdjęcia } \\
\text { pozytywne } \\
\text { niesympatyczne }\end{array}$} & \multicolumn{2}{c|}{$\begin{array}{c}\text { Zdjęcia } \\
\text { pozytywne } \\
\text { sympatyczne }\end{array}$} & $F$ & $d f$ & $p$ \\
\cline { 2 - 11 } & $M$ & $S D$ & $M$ & $S D$ & $M$ & $S D$ & $M$ & $S D$ & & & \\
\hline Znak emocji & $3,73^{a b}$ & 0,80 & $4,29^{c d}$ & 0,51 & $8,62^{a c}$ & 0,82 & $8,60^{b d}$ & 0,87 & 122,51 & 3,37 & $<0,001$ \\
\hline $\begin{array}{l}\text { Sympatycznośćn } \\
\text { nadawcy }\end{array}$ & $3,93^{a}$ & 0,63 & $6,10^{a}$ & 0,69 & $7,70^{a}$ & 0,53 & $8,77^{a}$ & 0,31 & 141,69 & 3,37 & $<0,001$ \\
\hline $\begin{array}{l}\text { Intensywność } \\
\text { ekspresji }\end{array}$ & $4,19^{a b}$ & 2,06 & $3,69^{c d}$ & 1,22 & $7,84^{a c}$ & 1,24 & $7,39^{b d}$ & 1,58 & 18,69 & 3,37 & $<0,001$ \\
\hline $\begin{array}{l}\text { Autentyczność } \\
\text { ekspresji }\end{array}$ & 6,81 & 1,39 & 6,89 & 1,81 & 7,28 & 1,31 & 7,78 & 1,21 & 0,93 & 3,37 & 0,437 \\
\hline $\begin{array}{l}\text { Atrakcyjność } \\
\text { nadawcy }\end{array}$ & 4,37 & 1,71 & 4,68 & 2,63 & 4,79 & 2,30 & 4,88 & 1,91 & 0,11 & 3,37 & 0,956 \\
\hline Jakość zdjęcia & 8,87 & 0,60 & 9,15 & 0,49 & 8,73 & 0,65 & 8,83 & 0,31 & 1,19 & 3,37 & 0,325 \\
\hline
\end{tabular}

Literami w indeksach górnych oznaczono pary średnich, które różniły się od siebie na poziomie $p<0,05$.

Źródło: opracowanie własne.

Tabela 2. Wyniki testu Levene'a jednorodności wariancji dla poszczególnych zmiennych

\begin{tabular}{|l|c|c|c|c|}
\hline \multicolumn{1}{|c|}{ Zmienna } & Test Levene'a & $d f 1$ & $d f 2$ & $p$ \\
\hline Znak emocji & 1,228 & 3 & 37 & 0,313 \\
\hline Sympatyczność nadawcy & 2,148 & 3 & 37 & 0,111 \\
\hline Intensywność ekspresji & 1,555 & 3 & 37 & 0,217 \\
\hline Autentyczność ekspresji & 1,896 & 3 & 37 & 0,147 \\
\hline Atrakcyjność nadawcy & 2,260 & 3 & 37 & 0,098 \\
\hline Jakość zdjęcia & 1,014 & 3 & 37 & 0,397 \\
\hline
\end{tabular}

Źródło: opracowanie własne. 
Wyodrębnione zestawy zdjęć posłużyły do stworzenia czterech wersji prezentacji (po jednej na każdy z warunków eksperymentalnych). W przypadku każdej prezentacji przeprowadzono losowanie kolejności zdjęć w sposób analogiczny jak poprzednio. Zasady umieszczania zdjęć w prezentacji pozostały takie same, jak w przypadku sędziowania ( 3 slajdy: jeden z numerem zdjęcia wyświetlany przez 3 sekundy; drugi z samym zdjęciem, którego pojawieniu się towarzyszył dźwięk migawki wyświetlany przez 6 sekund; trzeci z prośbą o jego ocenę wyświetlany przez 10 sekund). Dodano jedynie zdjęcie próbne, mające być dla badanego treningiem przed właściwą częścią zadania. Było to jedno ze zdjęć odrzuconych po ocenie sędziów kompetentnych. Kryterium wyboru była średnia ocena znaku emocji najbardziej zbliżona do wartości środkowej 5,00 i najniższe odchylenie standardowe. Fotografię tę umieszczono na początku każdej wersji prezentacji i opatrzono numerem 0 .

Badanych poinformowano, ze ich rolą jest ocena jakości zdjęć. Skonstruowano arkusze do oceny zdjęć dla badanych, na których uwzględniono ostrość i jasność, oceniane na 10-stopniowych skalach poprzez zakreślenie odpowiedniej liczby. Właściwe zadanie poprzedzone zostało instrukcją i oceną jednego próbnego zdjęcia.

W celu sprawdzenia skuteczności manipulacji zastosowano dwie skale 10-stopniowe: do oceny sympatyczności i atrakcyjności fizycznej osób przedstawionych na zdjęciach znajdujących się w prezentacji oraz odcinek do oceny przyjemności płynącej z oglądania zdjęć. Badany miał dokończyć zdanie: „Oglądanie zdjęć sprawiało, że było mi..." poprzez postawienie na nim pionowej kreski w dowolnym miejscu między „bardzo nieprzyjemnie” a „bardzo przyjemnie”. Odcinek miał długość $100 \mathrm{~mm}$, zatem zmienna ta przyjmowała wartości od 0 do 100. Na końcu arkusza dla badanego znalazło się miejsce na wpisanie danych demograficznych: płci, wieku i kierunku studiów lub zawodu. Podczas badania zbierano również inne dane, które jednak nie są przedmiotem niniejszego artykułu.

Badania odbyły się w Laboratorium Instytutu Psychologii Uniwersytetu Łódzkiego. W pomieszczeniu znajdowało się biurko z dwoma krzesłami: dla badanego i eksperymentatora oraz biały ekran, za którym stało jeszcze jedno krzesło. Na biurku leżał laptop i długopis. Uczestnika informowano, że bierze udział w ocenie materiału, który posłuży do przyszłych badań. Podczas procedury na ekranie komputera wyświetlana była przygotowana wcześniej prezentacja multimedialna ze zdjęciami twarzy, a osoba badana miała za zadanie oceniać ich ostrość i jasność. Następnie wypełniała arkusz, na którym zbierano dane niezwiązane z tematyką niniejszego artykułu, a na końcu oceniała, czy oglądane twarze były sympatyczne i atrakcyjne fizycznie oraz czy ich oglądanie było przyjemne i wypełniała metryczkę. Przez cały ten czas eksperymentator znajdował się w części pomieszczenia, w której był niemal niewidoczny dla badanego, by widok jego twarzy nie mógł wpływać na wyniki. Kiedy badany zgłaszał wykonanie wszystkich zadań, wyjaśniano jego ewentualne wątpliwości i pytano o odczucia. 


\section{WYNIKI}

Jako pierwszą przeprowadzono analizę rozkładów badanych zmiennych. W tab. 3 przedstawiono statystyki opisowe oraz wyniki testu Shapiro-Wilka, którego użyto do sprawdzenia normalności rozkładów. Analizy wykazały, że zmienna ocena przyjemności z oglądania zdjęć charakteryzuje się rozkładem normalnym, zaś rozkłady pozostałych zmiennych odbiegają od normalności. Porównywalna liczebność badanych w poszczególnych warunkach pozwoliła jednak na prowadzenie dalszych analiz za pomocą testów parametrycznych (Field, 2013).

Tabela 3. Statystyki opisowe badanych zmiennych

\begin{tabular}{|l|c|c|c|c|c|c|}
\hline \multicolumn{1}{|c|}{ Zmienna } & $M$ & SD & Min & Max & \multicolumn{2}{c|}{ Test S-W } \\
\cline { 5 - 8 } & & & & & $Z S-W$ & $p$ \\
\hline $\begin{array}{l}\text { Ocena sympatyczności } \\
\text { nadawców }\end{array}$ & 7,28 & 2,17 & 2 & 10 & 0,92 & $<0,001$ \\
\hline $\begin{array}{l}\text { Ocena atrakcyjności } \\
\text { fizycznej nadawców }\end{array}$ & 5,18 & 1,56 & 1 & 8 & 0,94 & 0,001 \\
\hline $\begin{array}{l}\text { Ocena przyjemności } \\
\text { z oglądania zdjęć }\end{array}$ & 62,84 & 17,50 & 12 & 100 & 0,98 & 0,163 \\
\hline
\end{tabular}

$Z S$ - $W$ - statystka testu Shapiro-Wilka.

Źródło: opracowanie własne.

Następnie przeprowadzono analizy mające na celu sprawdzenie, jak badani postrzegali twarze osób w zastosowanym materiale bodźcowym w zależności od ocen sympatyczności i znaku emocji dokonanych przez sędziów kompetentnych. Dla każdej ze zmiennych zależnych (ocena sympatyczności nadawców, ocena atrakcyjności fizycznej nadawców, ocena przyjemności z oglądania zdjęć) przeprowadzono dwie jednoczynnikowe analizy wariancji, w których czynnikami były znak emocji i sympatyczność (według ocen sędziów kompetentnych).

Wyniki analiz dla oceny sympatyczności twarzy osób na zdjęciach wykazały, że średnie oceny tej zmiennej nie różnią się istotnie między grupami, w których zastosowano zdjęcia o niskiej i wysokiej sympatyczności (ocenionej przez sędziów kompetentnych), $F(1,80)=0,93 ; p=0,337$. Uzyskano natomiast istotny efekt główny znaku emocji, $F(1,80)=64,78 ; p<0,001$. Badani oglądający zdjęcia osób wyrażających pozytywne emocje ocenili sympatyczność tych osób wyżej $(M=8,69 ; S D=1,49)$ niż badani oglądający zdjęcia osób wyrażających emocje negatywne $(M=5,80 ; S D=1,76)$. Zależność tę ilustruje rys. 1 .

W przypadku oceny atrakcyjności fizycznej osób na zdjęciach nie wykazano istotnych statystycznie różnic średnich w przypadku grup oglądających zbiory zdjęć różniące się sympatycznością ocenianą przez sędziów kompetentnych: $F(1,80)=1,84 ; p=0,179$, jak również między grupami oglądającymi zdjęcia z pozytywnymi i negatywnymi ekspresjami emocjonalnymi: $F(1,80)=0,22 ; p=0,641$. 


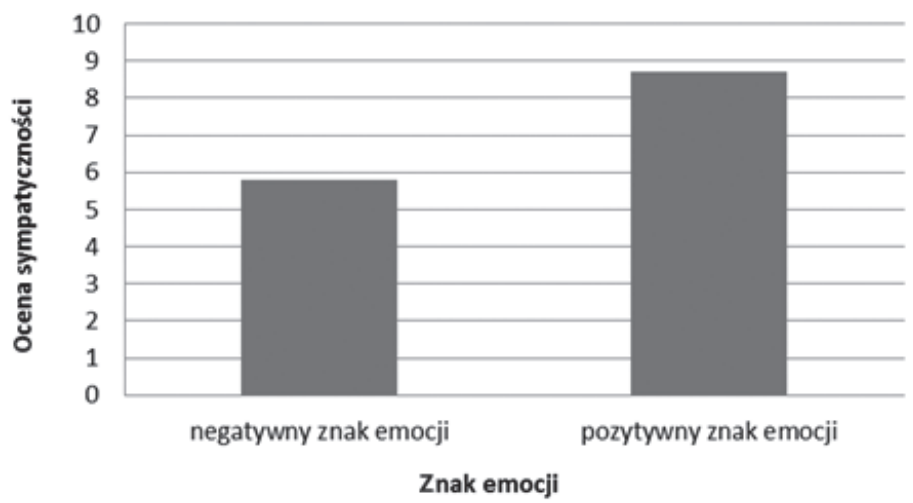

Rysunek 1. Zależność między znakiem emocji osób na zdjęciach a ocenami sympatyczności dokonywanymi przez badanych.

Źródło: opracowanie własne.

Analizy przyjemności z oglądania zdjęć wykazały, że średnie oceny tej zmiennej nie różnią się istotnie między grupami, w których oglądano zdjęcia o wysokiej i niskiej sympatyczności ocenionej przez sędziów kompetentnych: $F(1,80)=0,19$; $p=0,666$, natomiast istnieją istotne różnice w zakresie te zmiennej między grupami oglądającymi zdjęcia różniące się znakiem emocji: $F(1,80)=10,99 ; p=0,001$. Badani oglądający twarze o pozytywnej ekspresji emocjonalnej oceniali swoją przyjemność wyżej $(M=68,74 ; S D=17,98)$ niż ci, którzy oglądali twarze o negatywnych ekspresjach $(M=56,65 ; S D=14,80)$. Zależność tę ilustruje rys. 2 .

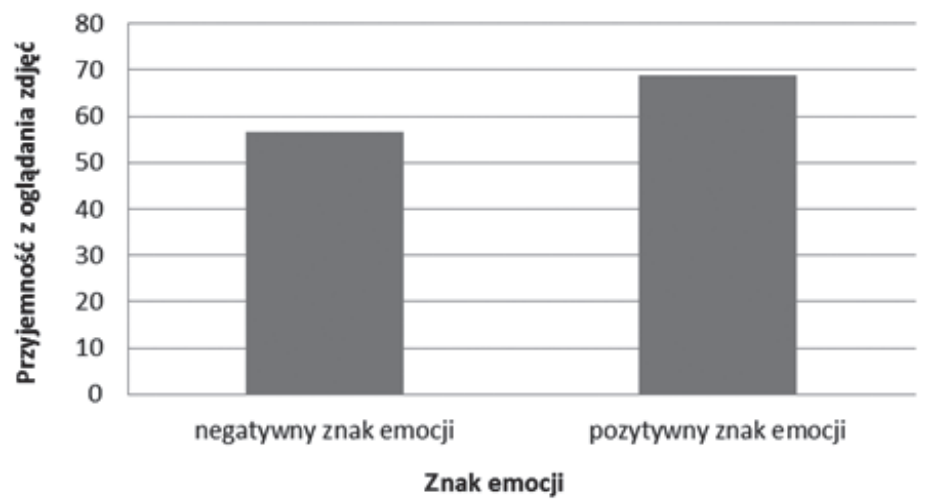

Rysunek 2. Zależność między znakiem emocji osób na zdjęciach a ocenami przyjemności z oglądania zdjęć dokonywanymi przez badanych

Źródło: opracowanie własne. 
W celu sprawdzenia, czy oceny sympatyczności różnią się w zależności od płci osób oceniających, przeprowadzono jednoczynnikową analizę wariancji, w której czynnikiem była płeć badanych. Nie wykazała ona istotnych statystycznie różnic między kobietami i mężczyznami w zakresie ocen sympatyczności twarzy osób oglądanych na zdjęciach: $F(1,80)=0,06, p=0,801$.

Dla ustalenia związków między ocenami sympatyczności nadawców, ich atrakcyjności fizycznej i przyjemności z oglądania zdjęć obliczono współczynnik korelacji $r$-Pearsona pomiędzy każdą z par tych zmiennych (por. tab. 4).

Tabela 4. Współczynnik korelacji $r$-Pearsona pomiędzy parami zmiennych: ocena sympatyczności nadawców, ocena atrakcyjności fizycznej nadawców, ocena przyjemności z oglądania zdjęć

\begin{tabular}{|l|c|c|c|}
\hline \multicolumn{1}{|c|}{ Zmienna } & $\begin{array}{c}\text { Ocena } \\
\text { sympatyczności } \\
\text { nadawców }\end{array}$ & $\begin{array}{c}\text { Ocena } \\
\text { atrakcyjności } \\
\text { fizycznej nadawców }\end{array}$ & $\begin{array}{c}\text { Ocena przyjemności } \\
\text { z oglądania zdjęć }\end{array}$ \\
\hline $\begin{array}{l}\text { Ocena sympatyczności } \\
\text { nadawców }\end{array}$ & 1 & $0,42^{* * *}$ & $0,62^{* * *}$ \\
\hline $\begin{array}{l}\text { Ocena atrakcyjności } \\
\text { fizycznej nadawców }\end{array}$ & $0,42^{* * *}$ & 1 & $0,27^{*}$ \\
\hline $\begin{array}{l}\text { Ocena przyjemności } \\
\text { z oglądania zdjęć }\end{array}$ & $0,62^{* * *}$ & $0,27^{*}$ & 1 \\
\hline
\end{tabular}

${ }^{* * *} p<0,001 ;{ }^{* *} p<0,01 ;{ }^{*} p<0,05$.

Źródło: opracowanie własne.

Wykazano istnienie umiarkowanych dodatnich korelacji między oceną atrakcyjności fizycznej nadawców a oceną ich sympatyczności oraz między oceną atrakcyjności fizycznej a oceną przyjemności z oglądania zdjęć, jak również silnej dodatniej korelacji między oceną sympatyczności nadawców a oceną przyjemności z oglądania zdjęć.

\section{DYSKUSJA WYNIKÓW I WNIOSKI}

Uzyskane wyniki wskazują, że oceny sympatyczności dokonane przez badanych różniły się od wydanych przez sędziów kompetentnych. Skoro sędziowie i badani nie zgadzali się w swoich ocenach, można przypuszczać, że to, które twarze ludzie uznają za sympatyczne jest kwestią subiektywną i nie ma uniwersalnych właściwości fizjonomii czyniących człowieka sympatycznym dla innych. Oceny sympatyczności dokonywane przez badanych były natomiast zależne od znaku emocji prezentowanych przez nadawców. Twarze uśmiechnięte były oceniane jako sympatyczniejsze niż twarze o negatywnych ekspresjach, co wydaje się zupełnie logiczne. Potwierdzono tym samym wyniki uzyskane przez Reysena (2006), z tą różnicą, że w niniejszym badaniu neutralną ekspresję emocjonalną zastąpiono negatywną. Przyjęte rozumienie sympatyczności zakłada, iż jest 
to cecha, która sprawia, że ma się ochotę na interakcję z daną osobą, a uśmiech nieznajomego jest rodzajem niewerbalnego wyrazu bycia przyjaznym, zatem postrzeganie nadawców o pozytywnych ekspresjach jako sympatycznych jest w pełni uzasadnione. Tę samą zależność dało się zresztą zaobserwować już na etapie sędziowania materiału bodźcowego, tym bardziej interesujący wydaje się brak zgodności w ocenach sympatyczności między sędziami kompetentnymi a badanymi. Obie grupy postrzegały uśmiechnięte twarze jako sympatyczniejsze, a jednak ich oceny różniły się. Rodzi się też pytanie, czy w ogóle możliwa jest wysoka ocena sympatyczności osób wyrażających negatywne emocje, lub niska ocena sympatyczności tych, które wyrażają pozytywne emocje. Intuicja podpowiada, że owszem, nie każdy uśmiech jest bowiem przyjazny, a smutna twarz może wzbudzać sympatię poprzez litość czy współczucie. Można jednak sądzić, że nie dobierając materiału w badaniu specjalnie pod tym kątem, raczej nie udałoby się uzyskać ocen sympatyczności na podobnym poziomie dla fotografii z twarzami o negatywnych i pozytywnych ekspresjach, gdyż, jak już wspomniano, uśmiech generalnie wzbudza większą sympatię niż smutek czy gniew. Warto wspomnieć, że jednocześnie nie wykazano wpływu znaku emocji na ocenę atrakcyjności fizycznej, zatem o ile osoby uśmiechnięte zazwyczaj wydają się sympatyczne, nie muszą przy tym być postrzegane jako atrakcyjne fizycznie.

Sympatyczność nadawców (oceniana przez badanych) okazała się jednak skorelowana dodatnio z ich atrakcyjnością fizyczną i przyjemnością z oglądania zdjęć. Tak jak wspomniano, sympatyczność i atrakcyjność fizyczna mogą być postrzegane jako podobne cechy i z pewnością często współwystępują. Oczywiste jest również, że patrzenie na twarze sympatyczne jest przyjemniejsze niż oglądanie twarzy niesympatycznych. Należy jednak zaznaczyć, że o ile korelację między sympatycznością a przyjemnością z oglądania zdjęć można uznać za silną, wykazana korelacja między sympatycznością a atrakcyjnością fizyczną była zaledwie umiarkowana, co może wskazywać, że jednak nie zawsze to, co piękne, okazuje się sympatyczne.

Przeprowadzone badanie nie było wolne od ograniczeń, które mogły wpłynąć na uzyskane wyniki. Grupa badanych składała się wyłącznie z osób w przedziale wiekowym 18-30 lat, co uniemożliwia generalizację wyników na ogół populacji. Wątpliwości budzi też stworzony materiał bodźcowy - po pierwsze, dobierając zdjęcia, nie kontrolowano wielu zmiennych, które mogły wywierać wpływ na badanych, takich jak: płeć nadawców, ich wiek czy kolor skóry. Fotografie dobrano do poszczególnych warunków eksperymentalnych na podstawie emocji wyrażanych przez przedstawiane osoby i ich sympatyczności ocenionej przez sędziów kompetentnych. Jak się jednak okazało, badani postrzegali sympatyczność nadawców inaczej niż oni. Należy wspomnieć, że grupę sędziów kompetentnych stanowiły osoby o nieco innej charakterystyce demograficznej niż badani - byli to wyłącznie studenci IV roku psychologii w wieku od 22 do 24 lat, w większości kobiety. Ta rozbieżność mogła sprawić, że między obiema grupami zaistniały różnice w ocenie 
nadawców. Możliwe też, że sympatyczność jest cechą postrzeganą w dużej mierze subiektywnie i nie istnieją obiektywne przesłanki do uznania danej twarzy za sympatyczną, co mogłoby tłumaczyć niezgodność sędziów i badanych.

Niestety, ze względu na przyjęcie określonego schematu badawczego nie było możliwe bardziej szczegółowe zbadanie kwestii różnic między obiema grupami. Być może na przykład nie wszystkie, a tylko niektóre fotografie wywoływały sprzeczne oceny - jednak to, że badani oceniali jedynie całe zestawy zdjęć, a nie poszczególne fotografie sprawiło, iż nie można było przyjrzeć się dokładniej przyczynie takich wyników. Ten sam problem dotyczy dokładniejszego zbadania różnic między płciami w postrzeganiu twarzy. W badaniu nie stwierdzono różnic w ocenach sympatyczności dokonywanych przez kobiety i mężczyzn, ale ponieważ oceny te dotyczyły całych zestawów fotografii, nie można na tej podstawie wysnuć kategorycznych wniosków. Interesującym zagadnieniem jest na przykład to, czy sympatyczność twarzy przedstawicieli każdej z płci ukazanych na zdjęciach była tak samo postrzegana przez mężczyzn i kobiety. W przyszłych badaniach warto byłoby zatem zweryfikować wpływ poszczególnych zmiennych związanych z wyglądem (np. wiek, kolor skóry) oraz płci na postrzeganą sympatyczność twarzy i rozstrzygnąć, czy zależność ta jest moderowana przez indywidualne preferencje tudzież płeć odbiorcy, czy może istnieje uniwersalny, przynajmniej w obrębie danej kultury, model sympatyczności. W dalszej perspektywie interesujące wydaje się również eksplorowanie możliwości wpływu postrzeganej sympatyczności twarzy danej osoby na postawy, emocje czy zachowania w sytuacjach społecznych.

\section{BIBLIOGRAFIA}

Aronson E., Wilson T. D., Akert R. M. (1997). Psychologia społeczna. Poznań: Zysk i S-ka.

Bar M., Neta M., Linz H. (2006). Very first impressions. Emotion, 6, 269-278.

Baumeister R. F., Leary M. R. (1995). The need to belong: Desire for interpersonal attachments as a fundamental human motivation. Psychological Bulletin, 117, 497-529.

Brodsky S. L., Griffin M. P., Cramer R. J. (2010). The Witness Credibility Scale: An outcome measure for expert witness research. Behavioral Sciences and the Law, 28, 892-907.

Bruce A. J., McDonald B. G. (1993). Face recognition as a function of judgements of likability/ unlikability. The Journal of General Psychology, 120, 451-462.

Cottrel C. A., Neuberg S. L., Li N. P. (2007). What do people desire in others? A sociofunctial perspective on the importance of different valued characteristics. Journal of Personality and Social Psychology, 92, 208-231.

Covin R. (2011). The need to be liked, http://books.google.pl/books?hl=en\&lr=\&id= bnsMflf$\mathrm{mXgC} \&$ oi $=$ fnd \&pg $=$ PA $1 \& \mathrm{dq}=$ the + need + to + be + liked \&ots $=$ rFY $5 \mathrm{KEGq} 6-\&$ sig $=$ FOsKQGKqjTGJbkZoF82LwcDFuQs\&redir_esc $=y \# v=$ onepage\&q=the $\% 20$ need $\% 20$ to $\% 20 \mathrm{be} \% 20$ liked\&f=false [dostęp: 24.07.2013].

Ebner N. C. (2008). Age of face matters: Age-group differences in ratings of young and old faces. Behavior Research Methods, 40, 130-136.

Field A. (2013). Discovering statistics using IBM SPSS Statistics. Los Angeles: Sage Publications. 
Galper R. E., Weiss E. (1975). Attribution to behavioral intentions to obese and normal-weight stimulus persons. European Journal of Social Psychology, 5, 425-440.

Hornby A. S. (red.) (1974). Oxford Advanced Learner's Dictionary of Current English. London: Oxford University Press.

Larrance D. T., Zuckerman M. (1981). Facial attractiveness and vocal likeability as determinants of nonverbal sending skills. Journal of Personality, 49, 349-362.

Reysen S. (2005). Construction of a new scale: The Reysen Likability Scale. Social Behavior and Personality, 33, 201-208.

Reysen S. (2006). A new predictor of likeability: laughter. North American Journal of Psychology, $8,373-382$.

Sprecher S., Regan P. C. (2002). Liking some things (in some people) more than others: Partner preferences in romantic relationships and friendships. Journal of Social and Personal Relationships, 19, 463-481.

Willis J., Todorov A. (2006). First impressions: Making up your mind after a 100-ms exposure to a face. Psychological Science, 17, 592-598.

\title{
JOANNA FILIPOWICZ
}

\section{FACE LIKEABILITY - INTRODUCTION TO THE ASSESSMENT OF DETERMINANTS}

\begin{abstract}
The goal of the current study was to make an introduction to exploring the determinants of face likability. It was also essential for the study to make a distinction between likeability and physical attractiveness since likeability hasn't been researched into in Polish studies so far. The influence of emotional expressions on the judgements of face likeability was also examined and the subjectivity of the judgements was explored.

82 subjects ( 41 men and 41 women) aged 18 to 30 participated in the study. The results indicated that likeability cannot be equated with physical attractiveness and that the judgements about it are made subjectively. It was also demonstrated that faces with positive emotional expressions may seem more likeable. There are still a lot of questions concerning face likeability that need to be answered; this study will hopefully encourage the further debate.
\end{abstract}

Keywords: likeability, face, first impression. 